\title{
MOTIVASI BISNIS MELALUI KEWIRAUSAHAAN GUNA MEMBERDAYAKAN KOPERASI SEKOLAH SEBAGAI SARANA BERWIRAUSAHA BAGI PESERTA DIDIK SMA NEGERI 2 PADANG PANJANG
}

\author{
Eliza $^{1}$, Jumiatul Mulya ${ }^{2}$, dan Nila Pratiwi ${ }^{3}$ \\ ${ }^{1,3}$ Fakultas Ekonomi dan Bisnis, Universitas Putra Indonesia "YPTK" \\ ${ }^{2}$ Program Studi Manajemen, Sekolah Tinggi Ilmu Ekonomi Perdagangan \\ E-mail: do.elizappn@yahoo.co.id
}

\begin{abstract}
ABSTRAK. Permasalahan yang dihadapi oleh SMA Negeri 2 Padang Panjang, Sumatera Barat terkait dengan jiwa kewirausahaan (enterpreneurship) yang perlu ditumbuhkembangkan kepada peserta didik. Oleh karena itu, penting dilakukan Program Kemitraan Masyarakat (PKM) Sekolah guna memecahkan masalah tersebut. Target (secara khusus) dari program ini adalah memberikan solusi melalui sosialisasi beserta pelatihan (workshop) kewirausahaan bagi peserta didik untuk memberdayakan koperasi sekolah sebagai sarana berwirausaha bagi peserta didik itu sendiri. Tujuan dengan adanya program ini adalah memberikan pemahaman tentang kewirausahaan kepada peserta didik, mengedukasi dan melatih peserta didik dalam berwirausaha agar mereka ulet, pantang menyerah, dan cerdas dalam memanfaatkan peluang yang ada untuk berwirausaha, menghidupkan koperasi sekolah dengan mengedukasi peserta didik tentang kewirausahaan, mampu meningkatkan kesejahteraan, bukan hanya dari sisi materil, namun kesejahteraan pola pikir kreatif, inovatif dan mandiri. Hasil dari program ini antara lain, yaitu koperasi sekolah yang semakin berkembang, membentuk jaringan pelajar enterpreneur sebagai wadah dan jaringan peserta didik yang berwirausaha bukan pada satu sekolah saja melainkan lintas sekolah dengan memanfaatkan sarana yang ada di sekolah-sekolah.
\end{abstract}

Kata Kunci: Motivasi; Kewirausahaan; Koperasi Sekolah; Peserta Didik

ABSTRACT. Problems faced by SMA Negeri 2 Padang Panjang, West Sumatra are related to entrepreneurial spirit (entrepreneurship) that needs to be developed for students. Therefore, it is important to do the School Community Partnership Program (PKM) to solve this problem. The target (specifically) of this program is to provide solutions through socialization along with entrepreneurship training (workshops) for students to empower school cooperatives as a means of entrepreneurship for students themselves. The purpose of this program is to provide students with an understanding of entrepreneurship, educate and train students in entrepreneurship so that they are resilient, never give up, and smart in utilizing the opportunities available for entrepreneurship, reviving school cooperatives by educating students about entrepreneurship, being able to improve welfare, not only in material terms, but the welfare of creative, innovative and independent mindsets. The results of this program, among others, are school cooperatives that are growing, forming a network of entrepreneurial students as a container and a network of students who are entrepreneurs not in just one school but across schools by utilizing existing facilities in schools.

Key words: Motivation; Entrepreneurship; School Cooperatives; Students

\section{PENDAHULUAN}

Saat ini pemerintah mendorong anak muda untuk mulai berani berwirausaha. Tujuannya adalah untuk membantu meningkatkan perekonomian keluarga dan dapat membuka lapangan pekerjaan. Program inilah yang gencar dilakukan oleh pemerintah kita sebagai upaya pemecahan masalah pengangguran dan kemiskinan di Indonesia dikarenakan dengan berwirausaha seseorang tidak akan lagi menganut prinsip klasik yaitu mencari sebuah pekerjaan, namun seseorang akan membuka lapangan pekerjaan bagi sesamanya. Tentunya dengan prinsip utama seperti ini, maka akan menyerap tenaga pengangguran disekitarnya. Seorang wirausahawan tidaklah harus orang yang mempunyai gelar/title akademis yang tinggi, mempunyai modal/capital yang besar, bukan juga orang yang mempunyai sumber daya alam dan insani yang tinggi. Namun seorang wirausahawan adalah orang yang mempunyai jiwa kreatif dan dapat memanfaatkan peluang sekecil apapun menjadi suatu yang bernilai tinggi. Kewajiban Seorang wirausaha diantaranya mau menggeluti usaha tidak sekedar ala kadarnya, akan tetapi dengan keberanian, kegigihan sehingga usahanya tumbuh, berikutnya bersahabat dengan ketidakpastian (Darmanto, 2017).

Peserta Didik adalah salah satu bibit unggulan menciptakan seorang wirausahawan yang ulet dan tangguh, hal ini dikarenakan pada usia peserta didik banyak ide-ide kreatif dan inovatif yang mereka dapat mereka tuangkan dan kembangkan melalui program wirausaha ini, selain itu lewat program ini pula dapat menyalurkan tenaga berlebih yang mereka miliki, agar tidak disalurkan melalui cara-cara negatif, seperti: tawuran, narkoba, dan lain sebagainya. Disisi lain dengan adanya konsep peserta didik wirausaha ini akan mempersiapkan para generasi muda yang berdikari untuk menyambut adanya pasar Masyarakat Ekonomi Asean (MEA), yang syarat akan persaingan dunia kerja dan usaha yang sangat ketat. Kalau tidak mulai dari peserta didik tentunya mereka akan sangat sulit bersaing dalam berwirausaha.

Koperasi sebagai gerakan ekonomi rakyat, dan merupakan salah satu pilar ekonomi, selayaknya perlu mendapat perhatian serius dari pemerintah. Disisi lain, salah satu upaya pemerintah dalam mengurangi pengangguran dan 
mengentaskan kemiskinan dilakukan melalui programprogram pemberdayaan ekonomi rakyat. Dengan demikian, melalui pemberdayaan koperasi diharapkan akan mendukung upaya pemerintah tersebut.

Menurut Undang-Undang Nomor 17 Tahun 2012, koperasi adalah badan hukum yang didirikan oleh orang perseorangan atau badan hukum koperasi, dengan pemisahan kekayaan para anggotanya sebagai modal untuk menjalankan usaha, yang memenuhi aspirasi dan kebutuhan bersama dibidang ekonomi, sosial, dan budaya sesuai dengan nilai dan prinsip koperasi.

Salah satu wadah yang tepat untuk seorang peserta didik dalam berwirausaha adalah melalui koperasi sekolah. Menurut Surat Keputusan Bersama antara Menteri Perindustrian, Menteri Koperasi, Menteri Pendidikan dan Kebudayaan, dan Menteri Dalam Negeri No. 331/M/ SK/10/1984; No. 126/M/KPTS/X/SK/10/1984; No. 0477/M/1984 dan No. 72/1984, koperasi sekolah adalah koperasi yang anggotanya para siswa, baik Sekolah Dasar, Sekolah Lanjutan Tingkat Pertama, Sekolah Lanjutan Tingkat Atas, dan lembaga pendidikan swasta maupun negeri di luar yang disebutkan.

Sekolah yang berpotensi dijadikan tempat pengembangan peserta didik dalam berwirausaha salah satunya adalah di SMA Negeri 2 Kota Padang Panjang, Sumatera Barat. Jumlah peserta didik pada sekolah ini berdasarkan informasi yang diperoleh dari Kepada Sekolah adalah sekitar 845 Siswa/wi, diantaranya Siswa/wi Kelas X sebanyak 350 Orang (10 Kelas), Siswa/wi Kelas XI sebanyak 274 Orang (8 Kelas), Siswa/wi Kelas XII sebanyak 241 Orang (7 Kelas). Dari 845 orang siswa/wi yang terdaftar, lebih kurang baru 3\% yang memanfaatkan keberadaan koperasi sekolah yang ada di SMA Negeri 2 Padang Panjang.

Lebih lanjut dalam program yang kami lakukan ini bagaimana memberdayakan koperasi sekolah sebagai sarana atau wadah untuk mengembangkan jiwa berwirausaha bagi peserta didik, khususnya pada SMA Negeri 2 Padang Panjang.

Berdasarkan hasil observasi awal yang dilakukan, bahwasanya setelah berdiskusi dengan Kepala Sekolah SMA Negeri 2 Kota Padang Panjang menyarankan agar jiwa berwirausaha tersebut ditumbuhkembangkan kepada peserta didik (siswa/wi) untuk menjadi peserta didik yang mandiri dan tangguh dalam menghadapi tantangan di masa yang akan datang khususnya menghadapi perkembangan zaman yang selalu berubah-ubah, dimana semakin sedikitnya lapangan pekerjaan yang tersedia, sedangkan pencari kerja semakin banyak. Oleh karena itu, perlu diberikan pemahaman kepada peserta didik tentang pemberian motivasi melalui kewirausahaan guna memberdayakan koperasi sekolah.

Solusi dari permasalahan mitra diatas adalah dengan melaksanakan Program Kemitraan Masyarakat Stimulus (PKMS) guna memberdayakan koperasi sekolah sebagai sarana berwirausaha bagi peserta didik pada SMA Negeri
2 Padang Panjang yaitu memberikan pemahaman tentang kewirausahaan kepada peserta didik, mengedukasi dan melatih peserta didik dalam berwirausaha agar mereka ulet, pantang menyerah, dan cerdas dalam memanfaatkan peluang yang ada untuk berwirausaha, menghidupkan koperasi sekolah dengan mengedukasi peserta didik tentang kewirausahaan, mampu meningkatkan kesejahteraan, bukan hanya dari sisi materil, namun kesejahteraan pola pikir kreatif, inovatif dan mandiri. Target dan Luaran yang akan dihasilkan dari kegiatan ini, sebagai berikut:

1. Mampu memahami tentang kewirausahaan;

2. Mampu memahami tentang koperasi sekolah;

3. Mampu memanfaatkan peluang yang ada untuk berwirausaha;

4. Mampu meningkatkan kesejahteraan perekonomian keluarga.

\section{METODE}

Metode yang dilakukan dalam kegiatan ini melalui beberapa tahapan, diantaranya: (1) Persiapan (Observasi Langsung); Observasi yang dimaksud dari kegiatan Program Kemitraan Masyarakat Stimulus (PKMS) ini adalah langsung datang ke lokasi, tempat dimana kemitraan ini dilaksanakan untuk mengetahui kondisi para peserta didik SMA Negeri 2 Padang Panjang yang akan diberikan ilmu bermanfaat dalam bentuk Sosialisasi dan Pelatihan mengenai Motivasi Bisnis, Kewirausahaan, Wirausaha, dan Koperasi Sekolah sebagai Objek untuk mengembangkan kreatifitas yang dimiliki peserta didik tersebut. (2) Sosialisasi; Tim Pelaksana akan memberikan sosialisasi berupa gambaran kegiatan yang akan dilaksanakan. Kegiatan ini dilaksanakan dengan metode ceramah dan tanya jawab. (3) Demonstrasi; Unjuk Kerja dari Hasil Sosialisasi dan Pelatihan, yang dalam hal ini melihat perkembangan sembilan (9) kelompok kerja (peserta didik) dalam menghasilkan produk. (4) Evaluasi Kegiatan; Mengukur Ketercapaian Hasil Kegiatan, artinya adanya penilaian yang dilakukan dari sembilan (9) kelompok kerja yang sudah dibentuk oleh Tim Program Kemitraan Masyarakat Stimulus (PKMS).

Peserta dari Program Kemitraan Masyarakat Stimulus (PKMS) adalah Peserta Didik (Siswa/wi) SMA Negeri 2 Padang Panjang. Peserta Didik akan dibimbing oleh Pemateri yang berkompeten pada bidangnya masingmasing.

\section{HASIL DAN PEMBAHASAN}

Kegiatan PKMS dilaksanakan sebanyak 11 kali pertemuan, setiap pertemuan akan dihadiri oleh Tim PKMS yang terdiri dari satu orang Ketua dan dua orang Anggota dengan melibatkan dua (2) orang mahasiswa, peserta didik yang sudah dipilih oleh pihak sekolah yang dalam hal ini SMA Negeri 2 Padang Panjang, serta seorang guru pendamping. 
Pertemuan awal merupakan pembukaan kegiatan dihadiri oleh Kepala Sekolah yang sekaligus membuka kegiatan kemitraan ini, Wakil Kurikulum, Guru Ekonomi (Guru Pendamping), Guru Pengelola Koperasi, Guru Agama yang Memimpin Do'a agar kegiatan ini mendapat berkah dari Allah SWT. Setelah kegiatan ini dibuka oleh Kepala Sekolah, maka tim Program Kemitraan Masyarakat Stimulus (PKMS) memperkenalkan diri. Suasana pertemuan awal bersifat formal dan menggunakan pendekatan persuasive dan terbuka. Para peserta didik diajak berdialog dan berdiskusi dengan teman sebayanya, dimana mereka saling berkenalan dikarenakan memiliki jurusan yang berbeda dan terpilih untuk mengikuti Program Kemitraan, Masyarakat Stimulus (PKMS) ini.

Pertemuan dengan pemateri difokuskan sebanyak tujuh (7) kali pertemuan adalah pemberian materi oleh pemateri yang ahli dibidangnya yaitu Bapak Hendri Maisoni, S.E., M.M. sebagai seorang motivator dan trainer. Pemberian motivasi kepada para peserta didik diharapkan dapat memberikan efek yang positif kepada peserta didik agar termotivasi untuk berwirausaha meskipun masih dengan modal yang terbatas.Bapak Drs. H. Syamsul Anwar., M.M. Pengawas Dinas Provinsi Sumatera Barat, Penulis Buku, dan Wirausahawan. Setiap materi yang diberikan oleh Bapak Syamsul Anwar tentang bagaimana cara supaya kita bisa menjadi seorang wirausahawan yang sukses sehingga mampu membuka/menciptakan lapangan pekerjaan. Berikutnya Bapak Dr. H. Novi Hendri, S.E., M.Si. Dosen, Anggota Dewan (DPRD Kota Padang Panjang), dan juga Wirausahawan. Materi yang diberikan oleh Bapak Novi Hendri berkaitan tentang bagaimana cara kita memanfaat peluang yang ada, terutama dalam memanfaat koperasi sekolah yang sudah ada atau kita sebagai pencetus dalam membentuk Koperasi Siswa di SMA Negeri 2 Padang Panjang.

Selama proses kegiatan berlangsung, dari 45 orang peserta didik yang sudah terpilih, tim PKMS langsung membagi mereka menjadi sembilan (9) kelompok dan setiap kelompok terdiri dari lima (5) orang. Diawal pertemuan setiap kelompok kami berikan tugas yang berkaitan dengan target luaran yang ada, yaitu memanfaatkan peluang yang ada untuk berwirausaha.

Setiap kelompok akan memiliki ketua, dan setiap ketua akan kami berikan tanggung jawab untuk mengelola uang sebesar Rp. 100.000 sebagai modal dalam setiap kelompok untuk berwirausaha. Setiap minggunya, ketua kelompok akan memberikan hasil pelaporan kegiatan mereka dalam berwirausaha. Berikut ini merupakan hasil kerja kelompok dari kegiatan PKMS.

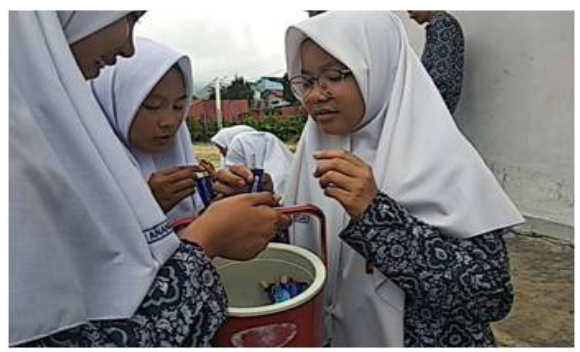

Gambar 1. Proses Penjualan

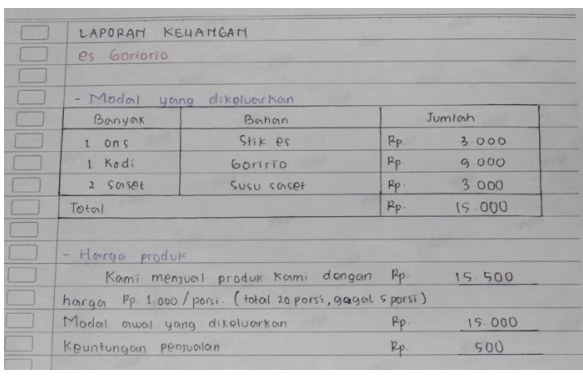

Gambar 2. Laporan Penjualan

Dikarenakan masih adanya kelompok yang tidak mendapatkan keuntungan dalam proses berwirausaha, maka perlu dilakukan kegiatan pelatihan. Kegiatan itu bertujuan untuk memberikan masukan dan kritikan kepada setiap kelompok agar lebih termotivasi dalam membuat dan menjual produknya. Tim PKMS secara pribadi melakukan pendekatan secara individu agar mereka dapat lebih leluasa untuk bertanya jawab tentang ide, kreatifitas, proses pembuatan, dan lain sebagainya.

Setelah kegiatan pelatihan dilakukan, maka tim juga akan melakukan kegiatan refleksi. Jarak antara kegiatan pelatihan dengan kegiatan refleksi alalah 4 Minggu, hal ini dikarenakan sesuai dengan jadwal yang sudah ditetapkan oleh Tim PKMS. Pada kegiatan pelatihan ini, setiap kelompok diwajibkan untuk mempresentasikan hasil penjualan mereka, mulai dari nama produk, foto produk, proses pembuatan, proses penjualan, sampai modal dan laba yang diperoleh. Berikut ini merupakan beberapa hasil dari penjualan dan laporan mingguan dari peserta PKMS.

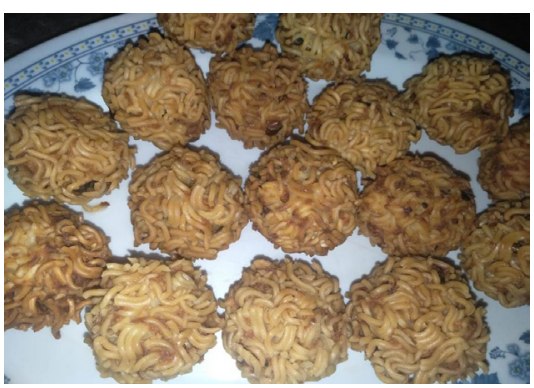

Gambar 3. Proses Penjualan

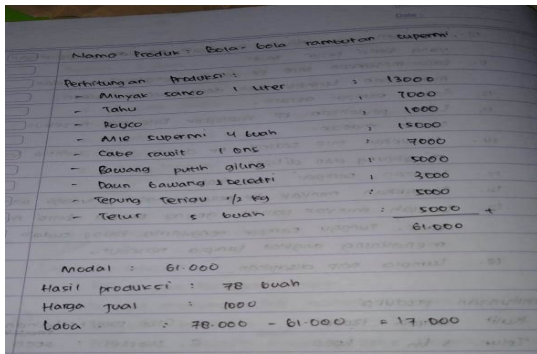

Gambar 2. Laporan Penjualan

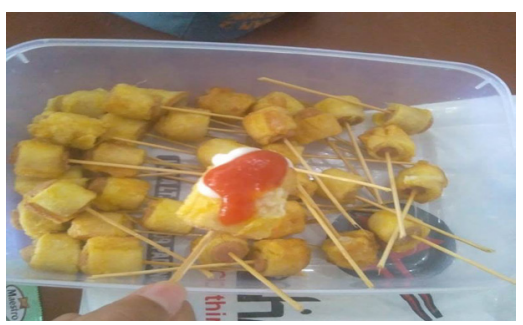

Gambar 1. Proses Penjualan 


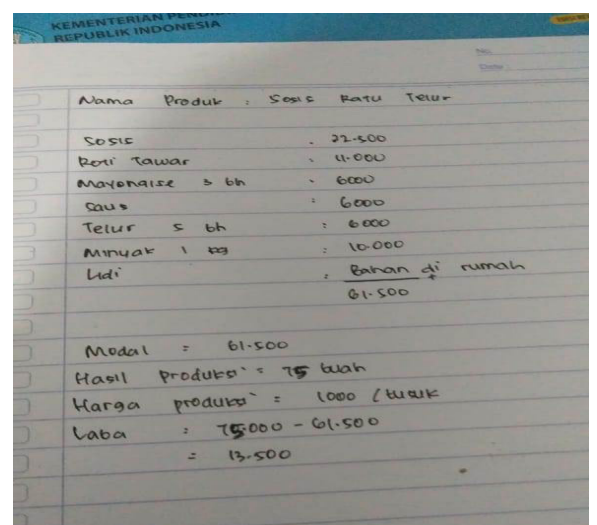

Gambar 2. Laporan Penjualan

Beberapa penjelasan yang sudah dijelaskan di atas, dapat dilihat bahwa setiap peserta didik sudah mampu untuk memproduksi produk-produk (makanan) dari kreatifitas dan keahlian yang dimiliki oleh Peserta Didik SMA Negeri 2 Padang Panjang yang sudah berani mencoba untuk menjadi entrepreneurship yang aktif dalam mencari informasi, kreatif dalam membuat produk, dan inovatif.

\section{SIMPULAN}

Berdasarkan pelaksanaaan program PKMS dapat disimpulkan bahwa: 1) peserta didik termotivasi untuk mengembangkan kreatifitas yang ada pada diri mereka, buktinya mereka mampu menciptakan produk (khususnya makanan) dengan kreasi dan inovasi, seperti beberapa hasil produk makanan diatas; 2) peserta didik mulai membuka cakrawala berpikir maju untuk menjadi wiraushawan muda yang sukses di masa depan dan mampu membuka lapangan pekerjaan bagi orang lain, buktinya mereka sangat aktif mengikuti kegiatan ini; 3) produk-produk (khususnya makanan) yang dihasilkan oleh peserta didik, tidak hanya mereka perjualbelikan di koperasi sekolah mereka saja atau kepada guru-guru mereka, tetapi mereka mencoba untuk memperjualbelikannya di luar sekolah mereka, buktinya dari dana yang diberikan kepada mereka walau tidak seberapa besarnya, mereka sudah mampu memperoleh keuntungan (profit).

\section{DAFTAR PUSTAKA}

Darmanto, (2017) Kewirausahaan, Pignatelli: Surakarta

http://anzdoc.com

http://sman2.sch.id

Undang-Undang Republik Indonesia Nomor 17 Tahun 2012.tentang Koperasi

Undang-Undang No. 25 Tahun 1992.tentang Koperasi 